\title{
What Is Esotericism? Does It Exist? How Can It Be Understood?
}

\begin{abstract}
The term "esotericism" has been used by practitioners since the late $18^{\text {th }}$ century to describe non-hegemonic ideas and practices. The ideas behind this term were mainly Christian ideas - or ideas from other sources (e.g. "pagan” ones), interpreted by Christians. In the $20^{\text {th }}$ century, the term esotericism became a scientific concept in Western Europe and North America, following a theological path which was opened in the $17^{\text {th }}$ century. This cultural relativity limits the possible application of this term to other regions, cultures or language traditions and claims to determine possible semantic, pragmatic or functional equivalents from a critical perspective. Consequently, there is no culturally invariant "essence" of "esotericism”. Each concept applied to "esotericism" contains only possible - not mandatory - features and involves normative decisions. If one uses such a "toolbox" of features, a comparison of different phenomena or traditions is only possible with regard to specific features or a group of features. Consequence: Concrete definitions of esotericism apply only to concrete fields of research - which means: Different definitions of esotericism will overlap. They will have family resemblances but never be identical. Since our concepts of esotericism will always be different, intercultural comparison will remain difficult. However, scholarly research must resist (over-)simplification when it comes to interpreting reality.
\end{abstract}

\section{The Religionist Problem of "Esotericism"}

The term "esotericism" (which will henceforth be used mainly without quotation marks) is a relatively recent production of the history of the English language. Comparable results are found for the other languages of Western Europe. ${ }^{1}$ This term first appeared in German in 1792 in a text on the "esotericism of the Order" of the ancient Pythagoreans, ${ }^{2}$ but remained extremely rare for a long time. It only began to take off in the last two decades of the $19^{\text {th }}$ century.

1 I would like to express my sincere thanks to Yves Mühlematter, Dimitry Okropiridze and Julian Strube for their critical reading and helpful hints.

2 Monika Neugebauer-Wölk, "Historische Esoterikforschung, oder: Der lange Weg der Esoterik zur Moderne,” in Aufklärung und Esoterik, vol. 3, Wege in die Moderne, ed. Monika NeugebauerWölk et al. (Berlin: de Gruyter, 2013), 41.

Ә Open Access. (C) 2021 Helmut Zander, published by De Gruyter. (cc) BY-NC-ND This work is licensed under a Creative Commons Attribution-NonCommercial-NoDerivatives 4.0 International License. 


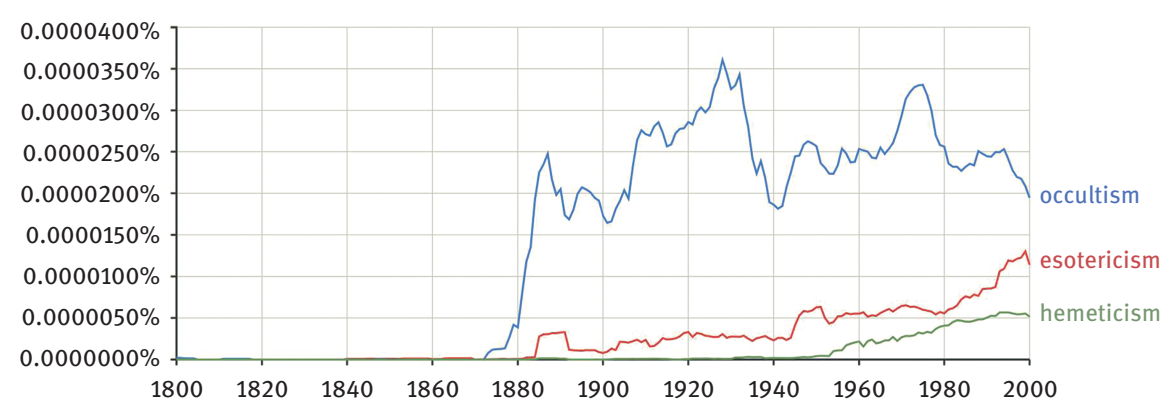

This also applies - as shown by a cursory glance at the books scanned by Google on the Ngram platform - to related and, at the same time, competing terms such as occultism or hermeticism.

The adjectives for these three terms are much older and date back to Antiquity.

This innovation in terms is not of secondary importance, because their history - as expounded upon by Reinhard Koselleck in the "Begriffsgeschichte"3makes one thing very clear: whenever a new noun appears, there are intellectual and social reasons for its creation, which, for the historian, contain important indications of mental or ideological changes. The traditional counterargument considers new terms to be irrelevant because the object (here: esoteric practices or ideas) exists long before the term (here: esotericism). Even if this argument were true - which I deny as a general rule - this would not eliminate the tension between signifiant and signifié - between term and object - because a term is always coined in a specific time and context. Therefore, two developments can only be understood in a given context: What exactly is meant by a term? And, above all: Why did a term have to be "invented"? Why did it not already exist (although, as the counterargument would have it, the object had already existed for some time)? A more precise reconstruction of the history of the term "esotericism" and of kindred terms, is difficult to achieve because users of the terms since the end of the $18^{\text {th }}$ century have not taken great care to define them. However, though detailed historical research on the history of the semantics of occultism, hermeticism and esotericism is lacking, some semantic fields can be roughly outlined. Around 1900, the term occultism, which appears as a noun around the middle of the $19^{\text {th }}$ century in France (presumably first used by Eliphas Lévi), ${ }^{4}$ had many

3 Reinhart Koselleck, Begriffsgeschichten (Frankfurt am Main: Suhrkamp, 2006); Reinhart Koselleck, ed., Historische Semantik und Begriffsgeschichte (Stuttgart: Klett-Cotta, 1979).

4 Julian Strube, "Occultist Identity Formations Between Theosophy and Socialism in fin-desiècle France,” Numen 64, no. 5/6 (2017): 568-595. 
points in common with the concept of (empirical) science. As a consequence, terms such as occult science, occult research, or, more concretely, occult chemistry or occult physics were either coined or gained in popularity (such as the "sciences occultes" in France). Hermeticism, which may have first appeared in the English language in the (late?) $19^{\text {th }}$ century, ${ }^{5}$ is likely to be more clearly defined because it is closely linked to the Neoplatonic tradition, which, in turn, goes back to a reference text - Marsilio Ficino's translation of the "Corpus Hermeticum" published in 1463. The concept of esotericism might be, at least today, the vaguest of the three. That being said, in view of the lack of research, my considerations are currently only plausible conjectures on a possible accumulation of features in certain contexts.

The reasons for the scarcity of academic research in this area (despite the widespread use of these terms and their associated practices into the late $20^{\text {th }}$ century) are known, at least in principle. The blurred boundary between practitioners and analysts, as documented in this volume, persisted among scientists well into the $20^{\text {th }}$ century, discrediting the entire field of research on esotericism, since, in the eyes of established scholars in religious studies, the research on esotericism was "corrupted" by ideological interests - or by the "religionists", as this group of scholars is called in academia. The highly influential scholar Frances Yates provides an example of the problematic adoption of terms in the object language ("Objektsprache") and at least some of the underlying "esoteric" concepts, ${ }^{6}$ but these debates are still ongoing. ${ }^{7}$

\section{Merits and Limits of the Scholarly Debates}

The most significant change in this situation occurred when Antoine Faivre ( $\left.{ }^{\star} 1934\right)$ entered the field. Faivre was trained as a literary scholar and was highly qualified in non-hegemonic currents of the early $19^{\text {th }}$ century. In 1979 , he was appointed “Chaire d'Histoire des courants ésotériques et mystiques dans l'Europe moderne et contemporaine" at the Sorbonne in Paris. Following his first writings, in

5 First appearance in 1894, according to: The Oxford English Dictionary, s.v. "hermetism"; There are older references in German; for example for 1709, cf. Florian Ebeling, Das Geheimnis des Hermes Trismegistos: Geschichte des Hermetismus (München: C. H. Beck, 2009), 71. However, a history of the term has only been briefly touched upon in research.

6 Wouter J. Hanegraaff, "Beyond the Yates Paradigm: The Study of Western Esotericisms between Counterculture and New Complexity,” Aries 1 (2001): 5-37.

7 Cf. the debate between Wouter Hanegraaff and Arthur Versluis; http://wouterjhanegraaff.blog spot.com/2018/06/esotericism-and-criticism-platonic.html [accessed on 30 September 2019]. 
which he appeared to be close to adopting a philosophia perennis, ${ }^{8}$ he became one of the primary historico-critical explorers of esoteric currents. In 1992, a booklet resulting from his work was published which contained a systematic outline for defining esotericism. "Esotericism", according to Faivre's concept, must contain four "critères nécessaires" for "une forme de pensée":?

- the interpretation of correlations as "les correspondences";

- the idea of "la Nature [sic] vivante";

- knowledge through "imagination" and "médiations" (transmission/transfer);

- the alteration of man by "l'expérience de la transmutation".

"Critères supplementaires" are, in his eyes, the formation of a "concordance" of all religious traditions and the "transmission" of knowledge in a masterdisciple relationship.

This systematisation represented an enormous step forward in making research on esoteric objects more scientific, but it turned out to be both a blessing and a curse. It offered a framework of categories that could be used to map, systematise and critically discuss the vast field of "esotericism". This was a clear advantage. At the same time, however, this was also a disadvantage since this concept, because of its clear and simple structure, took root without being discussed critically in large parts of research on esotericism, both among researchers working in the narrow field of esotericism and even more so among those working in scientific fields in which esotericism was only a part of the field of research. Nevertheless - and here lies an enduring problem - Faivre's concept enjoyed (and still enjoys) great popularity in scholarly reflections, ${ }^{10}$ and was even more popular in the non-academic world - even after it had long since been revised in the scientific debate.

Scientific criticism of Faivre's concept has been expressed in two areas: content and epistemology. When it comes to content, it soon became clear that some notions only fit into narrow segments of esoteric traditions; transmutation, for example, comes from alchemy. It would be difficult to apply it outside this field; in the end, it can only be used metaphorically. At the same time, and surprisingly at

8 Wouter J. Hanegraaff, Esotericism and the Academy: Rejected Knowledge in Western Culture (Cambridge: Cambridge University Press, 2012), 339-355; see also the short biography in this volume, p. 247f.

9 Antoine Faivre, L'ésotérisme (Que sais-je ? 1031) (Paris: Presses universitaires de France, 1992), 14-19.

10 Cf. the recent proposal of Peter-André Alt, Imaginäres Geheimwissen: Untersuchungen zum Hermetismus in literarischen Texten der Frühen Neuzeit (Göttingen: V\&R unipress, 2012), 41-42, which is only partly based on Faivre's concept. 
that, the dimension of the secret or hidden was missing in Faivre's list - although

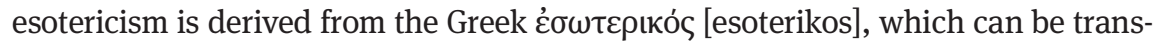
lated as inner, secret, hidden, concealed, arcane, occult, belonging to a circle of disciples. ${ }^{11}$ The term was later translated into the Latin "occultus", and finally, in the early $18^{\text {th }}$ century, the neo-Latin term "esotericus" appeared. ${ }^{12}$ Other possible characteristics, which may be found in scholarly literature, are also missing, such as the idea of universal knowledge ${ }^{13}$ or that of the connection between science and (religious) knowledge. ${ }^{14}$ Altogether, it turned out that Faivre's definition was (too) closely connected with the Romantic philosophy on nature, on which Faivre was an expert. Nevertheless, many scholars continued to define esotericism with content-related criteria, sometimes using new criteria (as discussed in chapter 3) or more cautiously speaking of "religious characteristics of esoteric spirituality". ${ }^{15}$ Others, however, refused to tie their scholarly work to a definition. ${ }^{16}$

With regard to epistemology, a radical critique of Faivre's and many other older works was made in 2004 by Kocku von Stuckrad, now a scholar in religious studies at the University of Groningen (the Netherlands). He proved that those who spoke of esotericism almost always projected their own ideas on esotericism into the sources without sufficiently asking whether these ideas were covered by the sources. ${ }^{17}$ He proposed the thesis that esotericism is a discursive construct; in other words, it is what followers or scientists think it is. A look at Wikipedia makes

11 Henry George Liddell and Robert Scott, comps., A Greek-English Lexicon, revised and augmented by H. St. Jones, with the assistance of R. McKenzie, 9th ed. (Oxford: Clarendon Press,

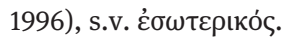

12 Neugebauer-Wölk, "Historische Esoterikforschung”, $64 \mathrm{f}$.

13 Andreas B. Kilcher, ed., Constructing Tradition: Means and Myths of Transmission in Western Esotericism (Leiden: Brill, 2010).

14 Egil Asprem, The Problem of Disenchantment: Scientific Naturalism and Esoteric Discourse, 1900-1939 (Leiden: Brill, 2014).

15 Goodrick-Clarke, Nicholas, The Western Esoteric Traditions: A Historical Introduction (Oxford: Oxford University Press, 2008), 4.

16 Such as (at least temporarily) in Hanegraaff, "Introduction”, in Dictionary of Gnosis and Western Esotericism, ed. Wouter J. Hanegraaff et al., vol. 1 (Leiden: Brill, 2005), xi: "It would have been unwise to link the present Dictionary too specifically to one particular definition or theoretical approach. Such an attempt would, moreover, have been unnecessary, because (. . .) scholars in this domain often strongly disagree about abstract theoretical definitions although they in fact share a broad consensus about the historical phenomena".

17 Kocku von Stuckrad, Was ist Esoterik? Kleine Geschichte des geheimen Wissens (München: C.H. Beck, 2004); for a detailed analysis, see Kocku von Stuckrad, Locations of Knowledge in Medieval and Early Modern Europe: Esoteric Discourse and Western Identities (Leiden: Brill, 2010), or, similarly, Olav Hammer, Claiming Knowledge: Strategies of Epistemology from Theosophy to the New Age (Leiden: Brill, 2001). 
it clear that he put his finger on a key issue. Here we find a diffuse field of terms. The German Wikipedia portal "Esoterik" contains twelve main terms: alchemy, anthroposophy, astrology, hermeticism, kabbala, magic, manticism, meditation, Rosicrucian, shamanism, thelema, Theosophy. These are followed by hundreds of keywords, of which I will only mention the first ten under the letter A: Abaris, Abraham von Worms, Abrakadabra, Achtsamkeitsmeditation, Adam Kadmon, adept, Adyar Library, affirmation, Agni yoga and Heinrich Cornelius Agrippa von Nettesheim. ${ }^{18}$ Stringent criteria for a definition are missing. This is admittedly a non-academic use of the term esotericism. However, if we examine the subjects addressed at the biennial conferences of the European Society for the Study of Western Esotericism (ESSWE), we find a narrower and more well-thought-out field of topics, though, in the end, these topics are still not clearly defined.

In this debate, Michael Bergunder, scholar for religious studies at the University of Heidelberg, has articulated the consequences even more radically than von Stuckrad: all our notions, including esotericism, are actually "empty signifiers" void of fixed content, ${ }^{19}$ since we always create meaning when we use terms. But in linguistic pragmatics, terms are not assigned content at random, because a term is bound to a language and thus to certain contexts, which entail the existence of content. Content is thus only created in specific contexts and, consequently, understandable only in these contexts. ${ }^{20}$ This definition brings to light the problem of the constructed nature of our concepts.

A key to understanding esotericism and related terms lies in reflecting on the genesis of this concept. Esotericism (inter alia) arose in demarcation from Christian theology, occultism (partly) in demarcation from the natural sciences of the $19^{\text {th }}$ century, hermeticism (also) in confrontation with $18^{\text {th }}$-century philosophy. Demarcation does not only mean that these concepts were formulated against certain positions or traditions, but also that they were already part of the counter position. Esotericism has thus not only arisen in conflict within and outside of Christian theologies but has also been shaped by Christian ideas (for instance, with regard to the relationship between the public and private spheres and be-

18 “Esoterik," Wikipedia, accessed on 4 August 2018. https://de.wikipedia.org/wiki/Portal: Esoterik ().

19 Even if this emptiness might be a "central moment of the discursive manufacture of meaning"; Michael Bergunder, "What is Esotericism? Cultural Studies Approaches and the Problems of Definition in Religious Studies,” Method and Theory in the Study of Religion 22 (2010): 23.

20 Michael Bergunder, "Was ist Religion? Kulturwissenschaftliche Überlegungen zum Gegenstand der Religionswissenschaft,” Zeitschrift für Religionswissenschaft 19 (2011): 3-55. The application of his theory on the concept of esotericism in Bergunder, "What is Esotericism?," 9-36. 
tween the institution and the individual, concretely with regard to mysterion/sacramentum) and was normally inseparable from Christian theology. This is part of an intensive and ongoing debate in the field of religious studies, since it has become clear that central analytical concepts are inextricably linked with Western and, more specifically, Christian concepts.

The last major proposal addressing the problem of a definition of esotericism was presented by Wouter J. Hanegraaff, who has held the chair of "Geschiedenis van de Hermetic filosofie en verwante stromingen" at the University of Amsterdam since 1999. In 2012, he presented an intellectually challenging publication on this topic, which remains probably the most important publication to date: "Esotericism and the Academy". One of his important findings was the evidence that the conception of a "heretical" tradition later called esotericism was to a considerable extent the result of Protestant controversial theology. Since the late $16^{\text {th }}$ century, theologians have identified spiritualistic and hermetic ideas within Christianity as non-orthodox and excluded them from the "orthodox" traditions. Ehregott Daniel Colberg, by means of his "Das Platonisch-Hermetisches [sic] Christenthum", is, in addition to Jakob Thomasius (before him) and Jakob Brucker (following him), probably a pivotal figure in this debate. ${ }^{21}$ Interestingly, he refused to draw a sharp distinction between spiritualistic and hermetic traditions, ${ }^{22}$ mainly because both (always, in Colberg's eyes) questioned the authority of the Bible by means of a theory of internal access to religious knowledge and their concept of the divine essence of man. The systematic consequences Hanegraaff drew from this can be found in the subtitle of the book, which considers esotericism as "rejected knowledge". In this perspective, everything that has been rejected in academic discourses or that theology has considered to be heresy can be labelled as

21 Ehregott D. Colberg, Das Platonisch-Hermetisches [sic] Christenthum, Begreiffend Die Historische Erzehlung vom Ursprung und vielerley Secten der heutigen Fanatischen Theologie unterm Namen der Paracelsisten, Weigelianer, Rosencreutzer, Quäcker, Böhmisten, Wiedertäuffer, Bourignisten, Labadisten und Quietisten: [Vol. 2] Darinn die Stücke der heutigen Fanatischen Theologie nach Ordnung der Glaubens-Artickel vorgetragen, aus den Schrifften der Schwärmer gründlich untersuchet, nach ihren rechten Verstand und Ursprung erördert, und aus Gottes Wort kurtz und deutlich widerleget werden (Frankfurt am Main: Weidmann, 1690/1691).

Hanegraaff, Esotericism and the Academy, 107-114, labelled him "the heresiologist" and was aware of the role that Jacob Thomasius played in the background, but things seem to be much more complicated, e. g. with regard to Italian debates surrounding Giovanni Battista Crispo; cf. Sicco Lehmann-Brauns, Weisheit in der Weltgeschichte: Philosophiegeschichte zwischen Barock und Aufklärung (Tübingen: Niemeyer, 2004), 26-27.

22 Lehmann-Brauns, Weisheit in der Weltgeschichte, 156-164. Cf. the ongoing debate on this question in Hans-Georg Kemper, "Hermetik - das 'Andere' im Luthertum: Zur Diskussion um die Anfänge deutscher Naturlyrik,” Zeitsprünge 20, no. 1/2 (2016): 2-14. 
“esotericism". This historical and normative distinction had then, according to Hanegraaff, also become the basis for the academic determination of the field of esotericism. By taking such a position, Hanegraaff was closely bound up with definitions of discourse theory as presented by Stuckrad and Bergunder. In these concepts, everything can become wrapped up in the content of a definition of esotericism. In Stuckrad's and Bergunder's view, scholars defined the content, while with Hanegraaff it was the theologians who did so by using the term esotericism. In all these perspectives, esotericism was the product of a process of negotiation, usually from asymmetrical positions, since the interpretive power of academic scholarship became stronger than that of practicing "esotericists" in the course of the $20^{\text {th }}$ century.

Nevertheless, following Hanegraaff's proposal contained its own problems. If everything that was rejected by academia were esotericism, one would ultimately have an extremely broad field in which any non-hegemonic thinking would be considered esoteric. In addition, there was a further problem: Hanegraaff himself, at the end of his volume, again reverted to defining esotericism in terms of content. Ultimately, there are, he wrote:

. . . very suggestive commonalities that structure the discourse as a whole; and in spite of its great diversity, it refers to real historical currents and ideas that are grouped under a label such as 'esotericism' not just arbitrarily, but for specific reasons that have as much to do with their own nature and intellectual content as with the discourse that constructs them as such. There is something "out there" after all ... An obvious red thread runs through my entire narrative in the four chapters of this book: we have seen that an intellectual culture grounded in biblical monotheism and Greek rationality was forced to come to terms with the presence of paganism. The development of what we now call Western esotericism is unimaginable without this fundamental fact. I will not try to summarize the argument in my previous chapters, but merely point out that the "wisdom of the pagans" was the heart and core of the ancient wisdom narrative, the central target of Catholic and (especially) Protestant polemicists culminating in the anti-apologetic current, and the principal object of ridicule for Enlightenment critics. ${ }^{23}$

The virtue and the strength of Hanegraaff's book, despite the sharp lines he draws in his discursive definition of esotericism, lie in the fact that he admits

23 Hanegraaff, Esotericism and the Academy, 369. Cf. Marco Pasi, "The Problems of Rejected Knowledge: Thoughts on Wouter Hanegraaff's Esotericism and the Academy," Religion 43 (2013): 201-212, and the debate in this volume of the journal "Religion". Concerning one element (the philosophy of identity as a core conviction), cf. Helmut Zander, "Das Konzept der 'Esoterik' im Bermudadreieck von Gegenstandsorientierung, Diskurstheorie und Wissenschaftspolitik: Mit Überlegungen zur konstitutiven Bedeutung des identitätsphilosophischen Denkens,” in Aufklärung und Esoterik: Wege in die Moderne, ed. M. Neugebauer-Wölk et al. (Berlin: de Gruyter, 2013), 113-135. 
that there are common elements which might apply to large parts of early modern esotericism and also, possibly, to the esotericism of the $19^{\text {th }}$ and $20^{\text {th }}$ centuries. Ultimately, as Hanegraaff makes clear several times in his book, early modern Christianity took issue with two elements: on the one hand, the (Neoplatonic) philosophy of identity, according to which God and the world, God and matter were only two sides of the same coin, and, as a consequence, the very essence of man was thought to be identical with the divine. A second point followed from this: in this conception, man possessed a direct relationship to the divine; he was no longer dependent on mediators (at least after receiving instruction from a master). Concerning this point, Protestant theologians started to distance themselves from orthodox Christianity towards the end of the $17^{\text {th }}$ century. In Catholic theology, on the other hand, in reaction to the Reformation, a theology developed starting in the $16^{\text {th }}$ century in which a multitude of places of revelation ${ }^{24}$ and an amalgamation with non-Christian traditions could legitimise religion; as a consequence, it explicitly distanced itself from occultism only in the $19^{\text {th }}$ century, and mildly and cautiously at that. At the beginning of the $19^{\text {th }}$ century (and perhaps earlier - there are no investigations concerning earlier centuries), many esotericists adopted the Protestant perspective. Hanegraaff regarded this as the core of the above-mentioned "pagan" tradition which the theologians turned against and in this paganism one again encounters (albeit not only) the Neoplatonichermetic tradition, since it could be regarded as a core element of paganism. This opens up a further problem in the definition of the content of esotericism, which is analogous to the question of the significance of the "secret" or the "hidden". It is evident that positions of philosophical identity, which aim at abolishing the difference between spirit and matter, and, in the end, frequently lead to the idea of a divine human being, play an important and often key role in "esoteric" ideas. And, of course, one can ask, along with Hanegraaff, whether this is not indeed a constitutive element of such traditions here.

That being said, another systematic problem of Hanegraaff's approach lies in the following pivotal point. Certain ideas which Hanegraaff (though this also applies to others) often called "rejected knowledge", were not exactly such. Often, the opposite was true. Hermetic ideas, for example, were part of the established theological and philosophical discourses in early modern times and among enlightened elites in the $18^{\text {th }}$ century. ${ }^{25}$ Although they could be the subject of theological controversies (which can be found much earlier, and more distinctively, in

24 Pivotal text: Melchior Cano, Locorum theologicorum libri duodecim (Venice: Rubinus, 1567). 25 Cf. Jan Assmann and Florian Ebeling, Ägyptische Mysterien: Reisen in die Unterwelt in Aufklärung und Romanti; Eine kommentierte Anthologie (München: C. H. Beck, 2011), 7-27 passim. 
Protestantism than in Catholicism), this did not mean that they were rejected knowledge. One such example is the history of religious studies, which is the subject of this volume. Here, around 1900, the contemporaries often did not know exactly where the boundaries between hegemonic and non-hegemonic knowledge should be set (as the present volume shows). If one approaches this question from the perspective of individual biographies, the matter starts to become completely confusing. Accepted and rejected knowledge were often intertwined, or "peacefully" coexisted side by side. An older historical example of these mergers are pietistic, hermetically influenced ideas that can be found in pietism itself, as well as in orthodox Protestantism or among dissenting Protestants, such as Baptists. ${ }^{26}$ In the Catholic Church, as one might expect from the aforementioned details, the conflicts were far less pronounced. Agostino Steuco (1496/97-1548), a polyglot scholar who preceded S. Marco in Venice (and thus presumably had access to Bessarion's library and its Neoplatonic texts), librarian of the Vatican Library and Council Father in Trento, was able to publish his Philosophia perennis, which gave this tradition its name, without encountering any problems. ${ }^{27}$ Furthermore, the Jesuit Athanasius Kircher was able to combine orthodox Catholic and hermetic positions without causing any major conflicts. ${ }^{28}$ Another (Protestant) example is given in Hans-Georg Kemper's important history of German Baroque poetry, in which he documents the high presence of hermetic ideas and the intrinsic connection - indeed, one might often speak of a fusion - between hermetic and other "hegemonic" ideas. ${ }^{29}$ In particular, Monika Neugebauer-Wölk,

26 Anselm Schubert, Täufertum und Kabbalah: Augustin Bader und die Grenzen der Radikalen Reformation (Gütersloh: Gütersloher Verlagshaus, 2008); Hermann Geyer, Verborgene Weisheit: Johann Arndts "Vier Bücher vom Wahren Christentum" als Programm einer spiritualistischhermetischen Theologie, 2 vols. (Berlin: de Gruyter, 2001); Hans-Georg Kemper, "Aufgeklärter Hermetismus: Brockes' Irdisches Vergnügen in Gott im Spiegel seiner Bibliothek,” in Aufklärung und Esoterik, ed. M. Neugebauer-Wölk with the assistance of H. Zaunstöck (Hamburg: Felix Meiner Verlag, 1999), 140-178. The starting point for the research on Goethe and his Protestant context: Rolf Christian Zimmermann, Das Weltbild des jungen Goethe: Studien zur hermetischen Tradition des deutschen 18. Jahrhunderts, vol 1, 2nd ed. (1969, enl. and rev. ed., München: Fink, 2002).

27 Agostino Steuco, De Perenni philosophia libri X (Lyon: Gryphius, 1540); cf. Wilhelm SchmidtBiggemann, Philosophia perennis: Historische Umrisse abendländischer Spiritualität in Antike, Mittelalter und Früher Neuzeit (Frankfurt am Main: Suhrkamp, 1998), 677-678.

28 Felicia Englmann, Sphärenharmonie und Mikrokosmos: Das politische Denken des Athanasius Kircher (1602-1680) (Köln: Böhlau, 2006).

29 Hans-Georg Kemper, Deutsche Lyrik der frühen Neuzeit, 6 vols. (Tübingen: M. Niemeyer, 1987-2002). In addition, cf. the intriguing dissertation by Kristine Hannak, Geist=reiche Critik. Hermetik, Mystik und das Werden der Aufklärung in spiritualistischer Literatur der Frühen Neuzeit (Berlin u.a.: de Gruyter, 2013). 
Professor Emerita for the History of the Enlightenment at the University of Halle, has investigated this connection for the early modern period using the keyword "Enlightenment and Esotericism"30 in the study of spiritualism. Friedemann Stengels most important book on Emanuel Swedenborg is another example of this entanglement, including the amalgamation of Christian ideas with concepts that were later labelled esoteric. ${ }^{31}$ However, the opposition to "modernity" had already been questioned earlier. ${ }^{32}$

In any case, it makes no sense to speak of independent esoteric traditions, because they are intricately intertwined with "hegemonic" ideas and form hybrids that elude clear separation. ${ }^{33}$ One can analytically distinguish the different traditions, but not, as the metaphors of heresy or rejection suggest, separate them. As a rule, it makes no sense to ask whether a tradition is (purely) esoteric, but only to what extent it contains ideas which are considered to be esoteric.

The de facto separation of research objects is - though this is of secondary importance here - often associated with another problem: the common - though obviously not ubiquitous - separation of research practices. In an ensuing intensive and unfinished scholarly debate in German Studies (see below), important topics from the Enlightenment, such as pantheism, deism or the understanding of history, are discussed, again against the background of the unclear boundaries between hermeticism and spiritualism that Colberg had already discussed at the end of the $17^{\text {th }}$ century. The fact that current research on esotericism apparently has not taken note of these discussions in literary studies (and vice versa) is a communicative problem in academic research, which might have promoted the notion of clear boundaries contra factum. Researchers who concentrate on esotericism are often insufficiently aware (or entirely unaware) of findings in neigh-

30 Monika Neugebauer-Wölk, ed. with the assistance of H. Zaunstöck, Aufklärung und Esoterik, vol. 1 (Hamburg: Meiner, 1999); Monika Neugebauer-Wölk, ed. with the assistance of Andre Rudloph, Aufklärung und Esoterik: Rezeption - Integration - Konfrontation, vol. 2 (Tübingen: Niemeyer, 2008); Monika Neugebauer-Wölk et al., ed.Aufklärung und Esoterik: Wege in die Moderne, vol. 3 (Berlin: de Gruyter, 2013).

31 Stengel, Friedemann, Aufklärung bis zum Himmel: Emanuel Swedenborg im Kontext der Theologie und Philosophie des 18. Jahrhunderts (Tübingen: Mohr Siebeck, 2011).

32 cf. Alex Owen, The Darkened Room: Women, Power, and Spiritualism in Late Victorian England (Chicago: University of Chicago Press, 1989), and especially Corinna Adele Treitel, A Science for the Soul: Occultism and the Genesis of German Modern (PhD diss., 1999, Baltimore: Johns Hopkins University Press, 2004).

33 Cf. Julian Strube, Sozialismus, Katholizismus und Okkultismus im Frankreich des 19. Jahrhunderts: Die Genealogie der Schriften von Eliphas Lévi (Boston: De Gruyter, 2016), 17-23, and his analysis of $19^{\text {th }}$-century French Catholicism. 
bouring disciplines. ${ }^{34}$ Let me give just one example. In German literature, there is an intensive debate surrounding the significance of hermetic traditions in which literary scholar Peter-André Alt (former president of the Freie Universität Berlin and current president of the German Hochschulrektorenkonferenz), following Kemper, has paid tribute to the great significance of hermetic traditions regarding the meaning of an "imaginäres Geheimwissen" (imaginary secret knowledge) for the transformation of anthropological and cosmological ideas from the Enlightenment, thereby methodically linking approaches from literary studies and from the history of knowledge. ${ }^{35}$ Volkhard Wels, Professor for the History of Knowledge at the Freie Universität Berlin, on the other hand, disagreed and partly denied the significance of hermeticism, mainly advocating the paramount significance of spiritualistic traditions. Pantheism, for example, had not been derived, in his perspective, from hermetic traditions; rather, he identified its sources in the work of "orthodox" reformers (Luther, Melanchthon) and in a "radikalem Spiritualismus". ${ }^{36}$ This thesis is at least structurally close to the abovementioned position of Colberg. Kemper recanted later in a monograph. ${ }^{37}$

This contention bears witness to a separation between disciplines, since, if I see it correctly, the debate on literature and philosophy in $18^{\text {th }}$-century Germany has not been perceived by those who claim to do research under the label of esotericism. This example in the field of early modern literature stands only pars pro toto as an example of the partial isolation of research on esotericism from research in other disciplines. Another neighbouring field in which the state of research is often lacking is the history of theology. However, the barriers to entry in this field are extremely high; on the one hand, because the centuries-long debates of theologians are often not accessible to scholars due to a lack of knowledge of Latin, and, on the other hand, because the scholarly analyses form an extremely large corpus. ${ }^{38}$

34 Other examples may be found in the sciences (e.g. in the fields of chemistry, alchemy or pharmacology), in philosophy or in the arts.

35 Alt, Imaginäres Geheimwissen.

36 Volkhard Wels, "Zwischen Spiritualismus, Hermetik und lutherischer 'Orthodoxie': Zu Hans-Georg Kempers Vorgeschichte der Naturlyrik,” Zeitsprünge 16, no. 3/4 (2012): 256-257, 284-285.

37 Kemper, "Hermetik".

38 However, this problem exists in varying degrees of severity. In the research on the early modern period there is, in part, an intensive reception of theological debates (cf., as an example, Peter J. Forshaw and Kevin Killeen, eds., The Word and the World: Biblical Exegesis and Early Modern Science (London: Palgrave Macmillan, 2007), or Hanegraaff, Esotericism and the Academy; for an indication of the problems, cf. Egil Asprem, "Esotericism and the Scholastic Imagination: The 
One can only suspect that the tendencies to delimit or separate esotericism as an object and as an academic discipline are linked to the occasionally insufficient reception of contributions from other disciplines. On the other hand, things become even more dramatic, insofar as there is often no reception of the conceptual debates on esotericism. This applies, anecdotally, to the entire debate previously mentioned in the field of German studies. Names like Faivre, Hanegraaff or Stuckrad are often sought in vain here. ${ }^{39}$

Let us return to the problems of discourse theory. The discursive concepts left the definition of esotericism open (or unclear). With the shift from content to a discursive practice (a far-reaching shift in the work of Stuckrad and Bergunder, a partial shift in the work of Hanegraaff), extremely different and broad definitions of esotericism became possible. The field of research benefited from this openness, because this renunciation of clear boundaries opened the door for the immense expansion of esoteric research into the most diverse times and contexts. There were hardly any limits to scientific curiosity, which the ESSWE conferences again show. This boundlessness is essential in order to be able to properly define an extremely controversial object. Research on esotericism is probably one of the "wildest" and most stimulating fields of research in cultural studies, in which disciplinary boundaries (one of the great catastrophes of the history of science since the $19^{\text {th }}$ century, since they separate intertwined topics) hardly play a role. The ESSWE networks which have emerged in recent years ${ }^{40}$ make clear which areas research on esotericism has spread to in the meantime. In addition to the regional networks (Central and Eastern Europe, Israel, Ireland, Italy, Scandinavia, South America), there are thematic networks on aesthetics, Antiquity, contemporary esotericism, Islam, mysticism, paganism, politics and gender. At the same time, one problem is evident: a person can understand, by means of discursive justification, nearly anything he or she wants about esotericism - including retreats to Faivre's proposal.

It seems to me that at least the following has become clear as a result of these deliberations:

1. It does not make sense to use such a narrow definition as Faivre's because it excludes too many phenomena while simultaneously postulating a general concept that is actually bound to particular cultural contexts.

Origins of Esoteric Practice in Christian Kataphatic Spirituality," Correspondences: Journal for the Study of Esotericism, 4 (2016): 3-36.

39 They are completely absent, for example, in Wels, "Zwischen Spiritualismus,"; Alt, Imaginäres Geheimwissen, and mostly absent in Kemper, "Hermetik," 14-15.

40 "Networks." ESSWE, accessed on 5 August 2019. https://www.esswe.org/Networks. 
2. At the theoretical level, discourse theory has made the constructed nature of a concept such as esotericism - and, ultimately, of all our concepts - clear. On the practical level, however, this has led to an insufficient reflection on the concept of esotericism. However, scholarly research that is unable to properly define the object of its research (and only as an analytical tool, which does not claim to mirror reality) has little chance of obtaining pertinent results.

In short, neither a strictly discourse-related nor a strictly content-related concept of esotericism provides a satisfactory solution to the conceptualisation of this field of research.

\section{Global Esotericism}

As an example, the problematic consequences of dealing with conceptual questions in an unsatisfactory way are obvious in a new field of research: esotericism outside of Europe, or esotericism as a "global” phenomenon. In 2018, the journal Correspondences: Online Journal for the Academic Study of Western Esotericism decided to forego the use of the adjective "Western". In addition to the hint at the increasing entanglement of cultures, "political and ideological motivations" in research were given as reasons for this renunciation. ${ }^{41}$ Such normative implications continue to play an important role in the intensifying debate surrounding the concept of global research on esotericism. Simultaneously, classical categories of comparative cultural research are only addressed to a small extent. Central issues in this debate would be methodical questions concerning entanglement, comparatistics and the transferability of terms and concepts. These elements have brought the older debates about postcolonial theory from the end of the $20^{\text {th }}$ century,

41 Aren Roukema and Allan Kilner-Johnson, “Time to Drop the 'Western,”' Correspondences: Journal for the Study of Esotericism 6, 2 (2018): 109-115. Concerning the older debate, cf. Kennet Granholm, "Locating the West: Problematizing the Western in Western Esotericism and Occultism," in Occultism in a Global Perspective, ed. Henrik Bogdan and Gordan Djurdjevic (Durham: Acumen, 2013), 17-36, who considers the term a relic of Western colonialism and therefore refrains from using it, or Wouter Hanegraaff, "The Globalization of Esotericism," Correspondences: Journal for the Study of Esotericism 3 (2015): 55-91, who proposes historicising the term instead of eliminating or repressing it. - A recent publication, which at least implicitly emphasizes Western characteristics, is Monika Neugebauer-Wölk's book Kosmologische Religiosität am Ursprung der Neuzeit 1400-1450 (Paderborn: Schöningh, 2019). 
which worked with relatively sharp demarcations of "cultures" and with strong asymmetries, to a complexity that has hardly become part of the reflection on a global concept of esotericism. From this perspective, at least two dimensions would have to be discussed. First, to what extent does a globally applied concept of esotericism constitute a continuation of the traditions of European imperialism will a European concept not once again become a matrix for the explanation of non-European cultures? Second, to what extent does a concept of esotericism that is not determined by regional or other contexts come close to an essentialist conception of esotericism? Does research thus return to an interpretation from which - as explained above - it had painstakingly liberated itself? Of course, one can justify any conceptual decision, with or without regional precision, but reflection on opportunities and risks is still in its early stages. Once again, a lack of interdisciplinary collaboration is noticeable here; the discussions are, to a large extent, conducted without including the dense corresponding reflections, for example, in literary studies, religious studies or ethnology, all disciplines which have been discussing the issues surrounding globalisation for a long time.

The consequences of these problems can be illustrated by the attempts to determine the relationship between esotericism and Islam (similar difficulties would arise in comparison with other religions ${ }^{42}$ ). At the inaugural Conference of the European Network for the Study of Islam and Esotericism in Venice in June 2018, ${ }^{43}$ the problem of definition in the Western debate became all the more acute in intercultural analysis. Basically, esotericism can be a translation of or refer to the Arabic term batin, which primarily evokes a semantic field, at the most basic level, centred on predicates such as secret, hidden and concealed. The pragmatic nature of the way the concept of esotericism was used at the Venice conference became quite clear when many participants confessed to have used the term "esotericism"

42 In 1883, the theosophist Alfred Percy Sinnett postulated the "Esoteric Doctrine" of an "Esoteric Buddhism", which was to be based on "the possession of spiritual faculties and perceptions of a higher order" (Alfred Percy Sinnett, Esoteric Buddhism (London: Trübner 1883), p. v.). However, Thomas William Rhys Davids, a British colonial official, Professor of Pāli at the University of London and editor of Buddhist Pali writings, vehemently disproved this view this three years later: "The original Buddhism was the very contrary of esoteric." (Thomas William Rhys Davids, Buddhism, Its History and Literature (New York: G. P. Putnam's Sons, 1896), 210.) Michel Pye, on the other hand, with regard to Japanese Buddhism, argued that "esoteric" did not mean something which was "not accessible to all", but "much more that some are already able to understand something and understand that others are still closed to it". (Michael Pye, "Entwicklung und Vielfalt des japanischen Buddhismus," in Der Buddhismus III. Ostasiatischer Buddhismus und Buddhismus im Westen, ed. Manfred Hutter (Stuttgart: Kohlhammer 2018), 291. 43 Organised by: Mark Sedgwick (Islamic studies), Francesco Piraino (sociology) and Dilek Sarmis (Turkology). 
in their lecture titles only because they wanted to fulfil the expectations of the organisers.

Meanwhile, in the published transactions, Sedgwick proposed a more detailed interpretation of the relationship between Islamic traditions and Western esotericism based on semantic analysis. In addition to batin, the word ghayb can also be situated in the semantic field of esotericism. ${ }^{44}$ In contrast to batin, however, ghayab appears in the Quran. In Sedgwick's eyes, "the main difference" on the conceptual level is that batin refers to "realities" while ghayb refers to "meanings and ideas"; ${ }^{45}$ thus, these two concepts can be related to content objects (batin) and to discursive concepts (ghayb). ${ }^{46}$

Nevertheless, how convincing is this intertwining of Western-Christian and Eastern-Islamic ideas when it comes to the concept of "esotericism"? Of course, there is a history of entanglement and exchange processes, which Sedgwick points out for example, in the reception of Neoplatonic concepts in the Arabic-speaking world, which led there to a concept of "esotericism", ${ }^{47}$ or later, in the $12^{\text {th }}$ and $13^{\text {th }}$ centuries in the Latin world, where they were mediated by Arabic literature, or, further, in the $19^{\text {th }}$ century through the reception of perennialist ideas from Europe in the Islamic world (some of which were then described as "esoteric"). ${ }^{48}$ Sedgwick now argues, similarly to Liana Saif, ${ }^{49}$ that the reception of Neoplatonic ideas in the philosophical traditions of Islam and, in this framework, the inclusion of ideas related to batin makes it possible to speak of "esoteric ideas" cism" in Islam. However, this is not entirely justified, since equating (or even establishing a relationship between) batin and "esoteric ideas" or "esotericism" seems to be (or is, in my eyes) a transfer of Western ideas into Arabic texts. This is where the problem lies: Neoplatonism itself is neither "esotericism" in today's

44 Mark Sedgwick, "Islamic and Western Esotericism”, Correspondences Journal for the Study of Esotericism 7, no. 1 (2019): 279-281.

45 Sedgwick, "Islamic and Western Esotericism," 281.

46 Sedgwick creates three epistemological categories in this context: a historical one that can be related to a "historical phenomenon", a "discursive tradition", and a "'rejected knowledge" or . . . 'a structural element in Western culture"'. This third dimension may be considered a sub-category of the discursive dimension. Sedgwick, "Islamic and Western Esotericism," 278-279.

47 "Ancient philosophy, and especially Neoplatonism, was also important for the development of a major historical body of Islamic bātin discourse including the ghayb that may, on that basis, be called 'Islamic esotericism'”; Sedgwick, "Islamic and Western Esotericism," 285.

48 Sedgwick, "Islamic and Western Esotericism,” 286-292.

49 Saif, Liana, "What is Islamic Esotericism?" Correspondences: Journal for the Study of Esotericism. vol 7, no. 1 (2019): 159.

50 Sedgwick, “Islamic and Western Esotericism,” 295; Saif, “What is Islamic Esotericism?”, 2. 
sense (and this also applies, as Sedgwick knows, to Plotinus's ideas, ${ }^{51}$ ) nor its root - and therefore its reception in Islam does not (necessarily) mean that esotericism was incorporated along with it.

This assumed esotericism in Islam can then, according to Sedgwick, become one of the starting points for a history of esotericism in the West: "Arabic sources, then, contributed to the early development of a form of Western esotericism [now without quotation marks, HZ] even before the Renaissance". ${ }^{52}$ In short, in this perspective, if we consider Neoplatonism to be a possible root of esotericism, then, in Islam, it gives rise to an Islamic esotericism which, in turn, becomes another form of esotericism in the West. However, each of these criteria for esotericism is an external ex post construction. Here, the suspicion arises that criteria that originate from the discussion about esotericism in Europe in the $19^{\text {th }}$ century are transported to earlier times and swept under the rug of other cultures. Since the $19^{\text {th }}$ century was the period when perennialist concepts of European provenance were received in Islamic countries - as a result of European imperialism and cultural exchange processes - this would correspond with other research on globalisation that asserts that the $19^{\text {th }}$ century was a crucial period in the history of modern globalisation. ${ }^{53}$ This view would not negate the extremely high importance of Neo-platonic ideas in a historical development which we describe using the label "esotericism" (furthermore, I maintain that the importance of this Ancient tradition is definitely underestimated in some research on Western "esotericism"), but rather claims to look for reliable arguments for the equivalence/relationship of batin/ghayb.

Boaz Huss, professor of Jewish Thought at Ben-Gurion University of the Negev and expert on Kabbalist traditions, pointed out, at the Venice conference, the importance of historicism in this "loose" use of the term esotericism in his reflections on the entanglement between Kabbalah, Sufism and esotericism. ${ }^{54}$ All these terms were massively (albeit to a different degree) shaped and normatively charged by the Western scholarship of the $19^{\text {th }}$ century. This cultural imprint does not exclude

\footnotetext{
51 Sedgwick, "Islamic and Western Esotericism," 285.

52 Sedgwick, "Islamic and Western Esotericism," 289.

53 Jürgen Osterhammel, Die Verwandlung der Welt. Eine Geschichte des 19. Jahrhunderts (München: Beck 2009). Many examples may be given. Cf. all the contributions in Correspondences: Journal for the Study of Esotericism, 7 no. 1 (2019), special issue Islamic Esotericism, (2019) or Thierry Zarcone, "Occultism in an Islamic context: the case of modern Turkey from the nineteenth century to the present time." In Occultism in a Global Perspective, ed. Henrik Bogdan and Gordan Djurdjevic (Durham: Acumen, 2013), 154-156, or the research of Alexandre Toumarkine (forthcoming).

54 Boaz Huss, "Kabbala and Sufism: Connection, Comparison and Mystification” (presentation, inaugural conference of the European Network for the Study of Islam and Esotericism: Common and Comparative Esotericisms; Western, Islamic, and Jewish, Venice, 13 June 2018).
} 
their use in other contexts, such as in Islam before the $19^{\text {th }}$ century. Nevertheless, it requires a reflection on the history of the construction of these concepts, on their cultural relativity and only then on possible commonalities and differences that can be associated with a term like "esotericism", however it is defined. If one refrains from using this critical approach, one threatens not to match the academic standards that have been instituted, ranging from hermeneutic to postcolonial reflection.

This being said, Sedgwick raises some important questions about esoteric research. On the one hand, he asks about different social conditions. He postulates that:

in the West, esotericism has generally been highly controversial, far more often rejected and repressed than promoted by the dominant culture and by religious authority. In Islam, esotericism in the form of Sufism has been controversial from time to time, sometimes repressed by the dominant culture and religious authority, but has far more often been promoted by them. ${ }^{55}$

If these two forms of esotericism are indeed comparable, tricky problems of comparatism arise. For comparison cannot only discuss similar structures or contents of concepts, but must include much more - for instance, the functional dimensions of the comparison and the social conditions which affect it (in this case, the different social structures of churches and Ummah and the resulting differences in dealing with "deviant", e.g. "esoteric" currents). Comparative research in religious studies has discussed these aspects in detail (see below), yet these discussions have not received sufficient attention in research on "esotericism". However, having such debates - and this is the pivotal point - presupposes that we are dealing with a comparable subject.

Furthermore, Sedgwick reminds us of a neglected area of esoteric research, namely the role of the hidden or the secret, which are key components of the terms ghayb and batin. This problem remains unresolved since the proposals of Faivre, who did not use this criterion of the hidden or the secret. Evidently, this does not apply to all phenomena that are considered esoteric, but it does apply to many. And, of course, as previously mentioned, this criterion is a key component of the term esotericism itself and, surprisingly, has not often been discussed in depth - not even as an additional or partial criterion - in scientific research. However, this has not silenced the question of why such an element could not be considered as a feature of esotericism, at least partially, in some traditions. Including this characteristic (though not to the exclusion of others) as one possible element would probably also liberate research on esotericism from its isolation

55 Sedgwick, "Islamic and Western Esotericism," 293; similar Saif, "What is Islamic Esotericism?," 47. 
and integrate it into the general history of religion, where a secret or concealed dimension is often discussed in research on "esoteric" traditions.

An intriguing example of this is the reflections of Jan Assmann, Emeritus Professor for Egyptology at the University of Konstanz and well known for his research on cultural memory, in his book Religio duplex. ${ }^{56}$ There, he discusses the relationship between open vs. secret and public vs. private practice as a fundamental tension in European religious history since Antiquity. This gives weight to the option of incorporating an "esoteric" element in the research on "esotericism". Assmann reflects on terms such as folk religion and mystery cults, hermeticism and esotericism, revelation and reason in this tension, including groups such as the freemasons and other "esoteric" currents. In this context, he analyses the genesis of religious studies ${ }^{57}$ and assigns significance to the concept of Religio duplex - and thus (partly) to what is known today as "esotericism" - because of its origin. Disciplinary boundaries play no role in Assmann's argumentation; interpreting the material within these borders would again conceal the dialectic presence of the open and hidden dimensions of religion that run across our established scholarly fields. Another researcher, the aforementioned Peter-André Alt, also drew heavily on this "esoteric" (i.e. hidden, concealed) dimension by interpreting German Baroque literature against the background of an alleged secret knowledge and its allegorical decipherment. ${ }^{58}$ The integration of the hidden or secret as a possible, not mandatory, feature of esotericism would also make it easier to relate Islamic traditions to Western esotericism, as not only Sedgwick, but also Saif, Cüneyd Yildirim ${ }^{59}$ and others have shown.

Ultimately, an issue is raised by the expansion of research on esotericism beyond modern Europe and Northern America: How Western is "Western esotericism"? Is there an Eastern one, as the logic of the term implicitly suggests? (Or a Northern or a Southern or a South-Western one . . . ?). It is clear that the term Western esotericism is not neutral - an "innocent" analytical term coined by academic research -, but rather a cultural construction and probably a child of theos-

56 Jan Assmann, Religio duplex: Ägyptische Mysterien und europäische Aufklärung (Berlin: Verlag der Weltreligionen, 2010).

57 Jan Assmann, “Das Geheimnis der Wahrheit: Das Konzept der 'doppelten Religion' und die Erfindung der Religionsgeschichte,” Archiv für Religionsgeschichte 3 (2001): 108-134.

58 Alt, Imaginäres Geheimwissen.

59 Cüneyd Yildirim, "Sufismus als Esoterik," Zeitschrift für junge Religionswissenschaft 13 (2018), accessed on 31 January 2019, doi: 10.4000/zjr.948; Zarcone, "Occultism in an Islamic context," 154-156; Saif, "What is Islamic Esotericism”, 25-33. 
ophy and the debates surrounding esotericism in the late $19^{\text {th }}$ century. ${ }^{60}$ The label "Western" was adopted by research on esotericism in the last quarter of the $20^{\text {th }}$ century as the field became more scientific, and with good reason. This confinement made it possible to limit the field geographically and to draw a line against perennialist concepts that advocated an idealistic, decontextualised and transcultural concept of esotericism. Since the critical revision of postcolonial theories, it has become clear, however, that different cultures are not directly confronted like the Eastern and Western blocks but are rather entangled in processes of exchange, and it is within these processes of exchange that "entities" such as esotericism are constructed. What this means for the concept of Western esotericism is only just now being debated. ${ }^{61}$ One enters here into the field of discussion both of exchange processes that question sharp demarcations, and, at the same time, of cultural grammars which enable us to describe stable developments in different cultures. Recent research, however, has made it very clear that at least that which has been referred to as "esotericism" since the $20^{\text {th }}$ century has developed in a process of exchange with the West - and that it was largely influenced by Western ideas (and vice versa). ${ }^{62}$

On the conceptual level, however, I do not see the necessity to conclude that the existence of a Western esotericism implies the existence of an Eastern, Northern or Southern esotericism: "Western" can be read as an indication of a regional limitation (as esotericism in the West or as a Western tradition) which would not entail the existence of a "Southern" esotericism or one from another region. To what extent it might ultimately be meaningful to speak of an Eastern or Western (or Buddhist, Jewish, Christian, Islamic, etc.) esotericism must be shown by the ongoing debate. However, if another religious, cultural or regional esotericism were coined, it would hold as much normative value as "Western" esotericism.

60 Strube, “Occultist Identity,” 568-595.

61 C.f. recently Julian Strube, "Towards the Study of Esotericism Without the 'Western': Esotericism from the Perspective of a Global Religious History," in New Approaches to the Study of Esotericism, ed. Egil Asprem and Julian Strube, (2021).

62 An analysis of the Ottoman Empire in the $19^{\text {th }}$ century c.f. Zarcone "Occultism in an Islamic Context," 157-176, who cautiously (using quotation marks) speaks of the genesis of a "Muslim 'Occultism”' (157) in this Islamic context. Likewise, the analysis of the role of René Guénon would illustrate this asymmetric entanglement. A magistral study on the French colonial period in North Africa by Alexandre Toumarkine is expected to be published. For now, see his lecture: Alexandre Toumarkine, "Tlemcen (Algeria): Would-be Fin de Siècle and Colonial Esoteric Setting," (presentation, inaugural conference of the European Network for the Study of Islam and Esotericism: Common and Comparative Esotericisms; Western, Islamic, and Jewish, Venice, 13 June 2018). 


\section{Proposal: An Open Concept of "Esotericism"}

In any case, it would make sense to sharpen the concept of esotericism and thus to make it practicable. Any solution must take two aspects into account:

1. All terms are the result of discursive definition. No concept of esotericism applies to all cultures or to all times.

2. The concept of esotericism is largely forged by (semantic) content stemming from Western/Christian traditions.

In the following, I propose a solution based on Benson Saler's reflections concerning the use of ethnocentric, relativistic concepts of religion from different cultures, thereby considering possible family resemblances (referring to Wittgenstein), ${ }^{63}$ as well as on Rodney Needham's concept of a polythetic classification and on Michael Stausberg's proposal for the practical application of concepts. ${ }^{64}$ The basis for these reflections is a discursive justification of the content of terms. Adopting this perspective, however, does not mean that this content is regarded as arbitrary, because of its pragmatic use.

- Characteristic elements. Components of a term, whether they are "found" in it or assigned to it posteriori, can be considered as representative or characteristic of said term. In this perspective, the assumption of family resemblances (in contrast with the biological metaphor) is also a cultural construction based on contingent decisions. ${ }^{65}$ There can be a "kinship" without common features - only based on resemblances. ${ }^{66}$ In a polythetic group, according to Rodney Needham, there is no attribute that all members of that group necessarily possess, and no member necessarily possesses all the attributes that are considered characteristic of that group. ${ }^{67}$ Following Wittgenstein, ${ }^{68}$ it is usage that creates a family resemblance between a group of terms. This resemblance has its origins in a "general term" that is applied to a certain group of objects. The criteria for determining such a general term, however, are different depending on which perspective is adopted (e.g. whether one is

63 Rodney Needham, "Polythetic Classification: Convergence and Consequences," Man NS 10 (1975): 349-369; Benson Saler, Conceptualizing Religion: Immanent Anthropologists, Transcendent Natives, and Unbounded Categories (Leiden: Brill, 1993).

64 Michael Stausberg, "Religion: Begriff, Definitionen, Theorien," in Religionswissenschaft, ed. Michael Stausberg (Berlin: de Gruyter, 2012), 42-44.

65 Cf. the critique in Bergunder, "Was ist Religion?," 8f.

66 Needham, "Polythetic Classification", 351.

67 Needham, "Polythetic Classification“, 363.

68 Rudolf Teuwsen, Familienähnlichkeit und Analogie: Zur Semantik genereller Termini bei Wittgenstein und Thomas von Aquin (Freiburg i. Br.: Alber, 1988), 48-101. 
considering function, form, content, appearance, etc.). Therefore, determining will remain subjective process. This very notion of family resemblance can be usefully applied in the field of religious studies ${ }^{69}$ and, specifically, with regard to the field of esotericism. In this case, terms such as rejected knowledge, secrecy, higher knowledge or transmutation are employed more frequently than emission standard, theory of probability, solar panels or stage fright. This accounts for the pragmatic use of practitioners, scholars or other observers. Such a definition does not lead to an idealistic or fundamental definition, because it depends on the pragmatic use of terms and on discursive decisions made by scholars. With this kind of definition, esotericism is always the result of a particular consensus - and remains only the result of a particular consensus.

- Probability. We can define characteristics, but we don't necessarily find them in a term. It is probable that a term like "secret" is a feature of esotericism, as shown in the attempts to define "batin", but it is not a mandatory component, as shown in the definition of Faivre, who refrains from using "le secret" or "le caché". Furthermore, there is no rule to determine the minimum number of elements used to define a subject that must be present in a term's definition; it is the task of the scholar to propose a definition, which, in turn, must be accepted by the scientific community.

- Cultural relativity. Any definition and any concept of esotericism is therefore culturally relative. It is thus primarily (though not exclusively) comprehensible in the culture in which it has been defined. However, its meaning changes with each transfer into a new context, especially through translation into another language. Consequently, the original meaning is only partially - if at all - preserved after an intercultural transfer or a translation and is inevitably infused with new information. Additionally, it is sometimes extremely difficult to find adequate terms for a translation - if they exist. To put it bluntly, concepts are ultimately untranslatable: ${ }^{70}$ Il traduttore è un traditore. More specifically, it is clear that the term esotericism is of Latin-Western origin and carries its Western-bound content. This historical path dependence cannot be eliminated, but only (and necessarily) problematised through ongoing critical reflection.

69 Cf. the application in Katja Rakow, Transformationen des tibetischen Buddhismus im 20. Jahrhundert. Chögyam Trungpa und die Entwicklung von Shambhala (Göttingen: Vandenhoeck \& Ruprecht, 2014).

70 Barbara Cassin, Vocabulaire européen des philosophies: Dictionnaire des intraduisibles (Paris: Le Robert, 2004). 
- Comparatistics. Such procedures can draw on fundamental insights of comparative methodology ${ }^{71}$ These determine commonalities (genera proxima) and differences (differentiae specificae) with regard to a point of comparison (tertium comparationis). Such a process is - and this is a central insight of the comparative approach - not neutral, but the result of normative determinations, in all three dimensions of comparison. Insofar as norms are never articulated and enforced independently of cultural contexts and power structures, this means that scholars involved in this process determine their object from a hegemonic position. Such asymmetry of power cannot be avoided, but, again, only continuously reworked and reflected on. Comparisons are always made when different objects are brought into a relationship: such was the case for the comparison between "heretical" or "orthodox" theology in early modern times, for the comparison of hermeticism, occultism and esotericism with "hegemonic" traditions, and, of course, for the comparison between Christian (Western?) and Islamic (Eastern?) "esotericism".

- Genealogical reconstruction. The identification of objects of comparison (which are always shaped by norms) assumes the existence of comparable objects in the past. ${ }^{72}$ However, in the process of writing history we have always (re-)constructed these objects. Although history runs from the past to the present, historiography writes history in the reverse direction, looking at the past from the present. Thus, what we identify as esotericism in any past or any area is not truly a past from of esotericism, but rather our perspective on an object which has been constructed for the purposes of comparison. Identifying the terms batin and/or ghayb as esotericism in an Islamic tradition - or "hermeticism" in the early modern Western period - stems not only from past conceptions, but also - and presumably primarily - from our own interests and knowledge. In this respect, any form of esotericism that we "discover" in the past exists only because we want to discover it, i.e. because we claim that these objects are comparable in structure and content.

71 Oliver Freiberger, Considering Comparison: A Method for Religious Studies (New York: Oxford University Press, 2019); James Mahoney and Kathleen Ann Thelen eds. Advances in Comparative-Historical Analysis, (Cambridge: Cambridge University Press, 2015).

72 Volkhard Krech, "Wer $\beta$ sagt, kann auch $\alpha$ sagen: Zu Reinhard Schulzes Ansatz der ,retrospektiven Genealogie‘," Islam in der Moderne, Moderne im Islam: Eine Festschrift für Reinhard Schulze zum 65. Geburtstag, ed. Florian Zemmin et al., (Leiden: Brill, 2018), 85-110; Reinhart Koselleck, Vergangene Zukunft: Zur Semantik geschichtlicher Zeiten (Frankfurt am Main: Suhrkamp, 1992). 
In practice, this means accounting for these selections when defining elements of a concept. More specifically, we as scholars must decide how and why we define a term such as esotericism on the basis of our research interests. We must determine its polythetic components, e.g. which terms, content and metaphors fit within a field. Possible features include: the marginality of groups, the secret/hidden, the theory of spirit and matter, the transfer of knowledge in a teacher-student relationship, the claim to universal knowledge and the pagan and/or Neoplatonic tradition. In addition, we must decide whether we prefer a more functional or sociological definition to a more content-oriented one: Esotericism as "rejected knowledge"? As knowledge critical of secularisation? As a worldview of the upper classes?

To put it in a nutshell: Concrete definitions of esotericism apply only to concrete fields of research. Consequently, as briefly mentioned: Different definitions of esotericism will overlap. They will have family resemblances but never be identical.

On the basis of these reflections, we can apply a term like esotericism to different spatial and temporal contexts. We can also transfer terms from one (religious) culture to another; knowledge of the logic underlying the construction of terms and the history of the use of such terms and ideas enable a critical reflection concerning their applicability. Researchers must ask themselves what content and what objects are being designated when they invoke the term or the concept of esotericism. This means, for example that the term "batin" in the work of Mansur al-Hallaj and the term "esotericism" in the work of Rudolf Steiner can overlap to varying degrees. Whether in Islam, for example, "batin" can be translated as esotericism is thus still to be decided; it is the task of scholarly discourse to resolve the question. Furthermore, this question obviously cannot be answered in the narrow space of theorising on "esotericism"; such an answer would have to integrate the results of concrete historical, sociological or ethnographic research.

At this point, I would like to make a proposal that draws on classical elements of scholarly work: at the beginning of each essay and of each monograph, we must clarify which elements we use to define our concept of "esotericism" and not simply assume that we will somehow share a common understanding of its definition. We must realise that this is and will remain a culturally bound conception which will undergo changes when it is used to interpret other cultures in the same way that it will surely undergo changes in the course of the ongoing scholarly debate. In the end, common elements might (and probably will) be found in different definitions of esotericism, but no general, "universal" concept of esotericism will emerge. This does not make scientific work easier, but it does make it more scientific. Obviously, by stating this, I doubt that Ockham's razor is 
an adequate tool for the analysis of cultural objects. Reality is always more complex than our (necessary and useful) analytical tools. Such instruments are necessary conditions for work in a scientific community, but, at the same time, also show the limits of scholarly work.

This way of analysing "esotericism" must also take personal dimensions and interests in the reflection on knowledge into account. Anyone who attempts to define esotericism must determine the extent to which he or she brings his or her own ideas to bear on a field of objects. Consequently, each definition tells us something about the interests of the researchers. This affects an extremely sensitive area of scholarly work: What is the relationship between a researcher's religious or ideological beliefs or convictions and practices on the one hand and his academic interests on the other? Once again, the connection between knowledge and interest is touched upon. Furthermore, when working in the field of biographies, we are faced with a dilemma: We must assume that there are junctions or overlaps, but at the same time we must respect the forum internum: Each person has the right to treat religion and other convictions as his or her own private matter. We often know from personal conversations or coincidences what a researcher thinks or practises in matters of religion or other convictions, but we do not make use of this knowledge. This is an ethical imperative. However, it is clear, as the biograms in this volume demonstrate, that interference is widespread in the field of historical studies on religion, and perhaps most notably in the research on esotericism. At present, biographical overlaps with esoteric beliefs or practices only come to light in exceptional cases, and often only in a certain phase of life, as illustrated by the cases of Antoine Faivre, Kocku von Stuckrad or Jeffrey Kripal mentioned in the introduction. However, as long as a researcher does not publicly disclose his or her beliefs or practices, we have no right to analyse this interior dimension concerning the relationship between knowledge and interest.

That means: Whether a term such as "esotericism" can then be meaningfully applied to a chosen subject must be demonstrated in the course of research. Ideally, the debate is an infinite, "abductive" (to borrow a term from Charles Pierce) process in which arguments are played back and forth between the field of study and its terms on the one hand and scholarly conceptualisation on the other. A back and forth game between the field of study and the development of the theory is necessary in order to create a term like esotericism.

A term coined in this way is dependent on the consensus of a scientific community. ${ }^{73}$ This means that researchers do not decide whether a definition is "true"

73 Bruno Latour and Steve Woolgar, Laboratory Life: The Social Construction of Scientific Facts (Beverly Hills: Sage, 1979). 
or "false"; rather, consensus is an indicator of the appropriateness of the term in relation to research questions. Its reception among scholars is quite likely to say something about its applicability. Of course, terms like esotericism can be used in a hegemonic way, which does not take into account their use in the sources, or their pragmatic use, for example, because it improves the conditions for research funding. It can also be used for pragmatic reasons due to a lack of alternatives or in the expectation that a concept will be clarified in the course of debates; this seems to be the case at numerous conferences on esotericism. However, scholarly research is not sustained merely from a somehow pragmatic use of a term or a concept, but also from the expectation that arguments will play a decisive role in the long run. We therefore need an ongoing debate on the possibility of using the term esotericism - keeping in mind that any definition, like any scientific statement, is relative and time bound, and that its meaning changes when it is transferred into another culture, another language or another system of symbolic forms.

We will then encounter the argument that research based on an open conception of esotericism shares no common basis of understanding. I would say, more tentatively, that the basis usually consists of partial commonalities. Any claim to a universal definition of esotericism raises the question of whether this definition is closer to utopia or to metaphysics. However, a more open conception would allow us to identify and discuss the problems openly, especially in intercultural encounters, and would no longer leave us faced with the aporia of a purely discursive or purely content-related definition of esotericism.

\section{Bibliography}

Alt, Peter-André. Imaginäres Geheimwissen: Untersuchungen zum Hermetismus in literarischen Texten der Frühen Neuzeit. Göttingen: Vandenhoeck \& Ruprecht unipress, 2012.

Asprem, Egil. The Problem of Disenchantment: Scientific Naturalism and Esoteric Discourse, 1900-1939. Leiden: Brill, 2014.

_ . "Esotericism and the Scholastic Imagination: The Origins of Esoteric Practice in Christian Kataphatic Spirituality." Correspondences: Journal for the Study of Esotericism 4 (2016): 3-36.

Assmann, Jan. “Das Geheimnis der Wahrheit: Das Konzept der 'doppelten Religion' und die Erfindung der Religionsgeschichte.” Archiv für Religionsgeschichte 3 (2001): 108-134.

—. Religio duplex: Ägyptische Mysterien und europäische Aufklärung. Berlin: Verlag der Weltreligionen, 2010.

—. and Florian Ebeling. Ägyptische Mysterien: Reisen in die Unterwelt in Aufklärung und Romantik: Eine kommentierte Anthologie. München: C. H. Beck, 2011. 
Bergunder, Michael. "Was ist Religion? Kulturwissenschaftliche Überlegungen zum Gegenstand der Religionswissenschaft.” Zeitschrift für Religionswissenschaft 19 (2011): 3-55.

- "What is Esotericism? Cultural Studies Approaches and the Problems of Definition in Religious Studies." Method and Theory in the Study of Religion 22, 1 (2010): 9-36.

Cano, Melchior. Locorum theologicorum libri duodecim. Venice: Rubinus, 1567.

Cassin, Barbara. Vocabulaire européen des philosophies: Dictionnaire des intraduisibles. Paris: Le Robert, 2004.

Colberg, Ehregott Daniel. Das Platonisch-Hermetisches [sic] Christenthum, Begreiffend Die Historische Erzehlung vom Ursprung und vielerley Secten der heutigen Fanatischen Theologie unterm Namen der Paracelsisten, Weigelianer, Rosencreutzer, Quäcker, Böhmisten, Wiedertäuffer, Bourignisten, Labadisten und Quietisten: [vol 2:] Darinn die Stücke der heutigen Fanatischen Theologie nach Ordnung der Glaubens-Artickel vorgetragen, aus den Schrifften der Schwärmer gründlich untersuchet, nach ihren rechten Verstand und Ursprung erördert, und aus Gottes Wort kurtz und deutlich widerleget werden. Frankfurt am Main/Leipzig: Weidmann, 1690-1691.

Ebeling, Florian. Das Geheimnis des Hermes Trismegistos: Geschichte des Hermetismus. München: C. H. Beck, 2009.

Englmann, Felicia. Sphärenharmonie und Mikrokosmos: Das politische Denken des Athanasius Kircher (1602-1680). Köln: Böhlau, 2006.

Faivre, Antoine. L'ésotérisme (Que sais-je? 1031). Paris: Presses universitaires de France, 1992.

Forshaw, Peter J., and Kevin Killeen, eds. The Word and the World. Biblical Exegesis and Early Modern Science. London: Palgrave Macmillan, 2007.

Freiberger, Oliver. Considering Comparison: A Method for Religious Studies. New York, NY: Oxford University Press, 2019.

Geyer, Hermann. Verborgene Weisheit: Johann Arndts "Vier Bücher vom Wahren Christentum" als Programm einer spiritualistisch-hermetischen Theologie. 2 vols. Berlin/New York: de Gruyter, 2001.

Goodrick-Clarke, Nicholas. The Western Esoteric Traditions: A Historical Introduction. Oxford: Oxford University Press, 2008.

Granholm, Kennet. "Locating the West: Problematizing the Western in Western esotericism and occultism." In Occultism in a Global Perspective, edited by Henrik Bogdan and Gordan Djurdjevic. Durham: Acumen, 2013: 17-36.

Hammer, Olav. Claiming Knowledge: Strategies of Epistemology from Theosophy to the New Age. Leiden: Brill, 2001.

Hanegraaff, Wouter Jacobus. "Beyond the Yates Paradigm: The Study of Western Esotericisms between Counterculture and New Complexity." Aries 1 (2001): 5-37.

_. "The Globalization of Esotericism." Correspondences: Journal for the Study of Esotericism 3 (2015): 55-91.

- Esotericism and the Academy: Rejected Knowledge in Western Culture. Cambridge: Cambridge University Press, 2012.

_. "Introduction." In Dictionary of Gnosis and Western Esotericism, 2 vols., edited by Hanegraaff in collaboration with Antoine Faivre, Roelf van den Broek, and Jean-Pierre Brach, Leiden/Boston: 2005. vol. 1, vii-xiii.

Hannak, Kristine. Geist=reiche Critik. Hermetik, Mystik und das Werden der Aufklärung in spiritualistischer Literatur der Frühen Neuzeit, Berlin: de Gruyter, 2013. 
Huss, Boaz. “Kabbala and Sufism: Connection, Comparison and Mystification.” Presentation, inaugural conference of the European Network for the Study of Islam and Esotericism: Common and Comparative Esotericisms; Western, Islamic, and Jewish, Venice, 13 June 2018.

Kemper, Hans-Georg. “Aufgeklärter Hermetismus: Brockes’ Irdisches Vergnügen in Gott im Spiegel seiner Bibliothek." In Aufklärung und Esoterik, edited by Monika NeugebauerWölk with the assistance of Holger Zaunstöck, 140-178. Hamburg: Felix Meiner Verlag, 1999.

—. Deutsche Lyrik der frühen Neuzeit, 6 vols. Tübingen: M. Niemeyer, 1987-2002.

—. "Hermetik - das 'Andere' im Luthertum. Zur Diskussion um die Anfänge deutscher Naturlyrik.” Zeitsprünge 20, no. 1/2 (2016) [the whole volume].

Kilcher, Andreas B., ed. Constructing Tradition: Means and Myths of Transmission in Western Esotericism. Leiden/Boston: Brill, 2010.

Koselleck, Reinhart. Begriffsgeschichten. Frankfurt am Main: Suhrkamp, 2006.

—. ed. Historische Semantik und Begriffsgeschichte. Stuttgart: Klett-Cotta, 1979.

- Vergangene Zukunft: Zur Semantik geschichtlicher Zeiten. Frankfurt am Main: Suhrkamp, 1992.

Krech, Volkhard. "Wer $\beta$ sagt, kann auch $\alpha$ sagen. Zu Reinhard Schulzes Ansatz der ,retrospektiven Genealogie‘," In Islam in der Moderne, Moderne im Islam: Eine Festschrift für Reinhard Schulze zum 65. Geburtstag, edited by Florian Zemmin et al. 85-110, Brill: Leiden/Boston 2018.

Latour, Bruno, and Steve Woolgar. Laboratory Life: The Social Construction of Scientific Facts. Beverly Hills: Sage, 1979.

Lehmann-Brauns, Sicco. Weisheit in der Weltgeschichte: Philosophiegeschichte zwischen Barock und Aufklärung. Tübingen: Niemeyer, 2004.

Liddell, Henry George, and Robert Scott. A Greek-English Lexicon. Rev. and augm. throughout by Henry Stuart Jones, with the assistance of Roderick McKenzie. Oxford: Clarendon Press, 1996.

Mahoney, James, and Kathleen Ann Thelen, eds. Advances in Comparative-Historical Analysis. Cambridge: Cambridge University Press, 2015.

Needham, Rodney. “Polythetic Classification: Convergence and Consequences.” Man NS 10 (1975): 349-369.

Neugebauer-Wölk, Monika, ed. Aufklärung und Esoterik. Vol. 1, with the assistance of Holger Zaunstöck. Hamburg: Meiner, 1999.

—, ed. Aufklärung und Esoterik. Vol. 2, Rezeption - Integration - Konfrontation. With the assistance of Andre Rudloph. Tübingen: Niemeyer, 2008.

—, Renk Geffarth, and Markus Neumann, eds. Aufklärung und Esoterik. Vol. 3, Wege in die Moderne. Berlin/Boston: de Gruyter, 2013.

__. "Historische Esoterikforschung, oder: Der lange Weg der Esoterik zur Moderne." In Aufklärung und Esoterik: Wege in die Moderne, edited by Monika Neugebauer-Wölk, Renko Geffarth and Markus Meumann, 37-72. Berlin: de Gruyter, 2013.

- Kosmologische Religiosität am Ursprung der Neuzeit 1400-1450. Paderborn: Schöningh, 2019.

Osterhammel, Jürgen. Die Verwandlung der Welt. Eine Geschichte des 19. Jahrhunderts. München: Beck, 2009.

Owen, Alex. The Darkened Room: Women, Power, and Spiritualism in Late Victorian England. Chicago: University of Chicago Press, 1989. 
Treitel, Corinna Adele. A Science for the Soul: Occultism and the Genesis of German Modern. PhD diss. 1999. Baltimore/London: Johns Hopkins University Press, 2004.

Pasi, Marco. "The Problems of Rejected Knowledge: Thoughts on Wouter Hanegraaf's Esotericism and the Academy." Religion 43 (2013): 201-212.

Pye, Michael. "Entwicklung und Vielfalt des japanischen Buddhismus." In Manfred Hutter, ed. Der Buddhismus und nicht drei: Ostasiatischer Buddhismus und Buddhismus im Westen 229-375. Stuttgart: Kohlhammer, 2018.

Rakow, Katja. Transformationen des tibetischen Buddhismus im 20. Jahrhundert: Chögyam Trungpa und die Entwicklung von Shambhala. Göttingen: Vandenhoeck \& Ruprecht, 2014.

Roukema, Aren, and Allan Kilner-Johnson. "Time to Drop the 'Western."' Correspondences: Journal for the Study of Esotericism 6, no. 2 (2018): 109-115

Rhys Davids, Thomas William. Buddhism: Its History and Literature. New York: G. P. Putnam's Sons, 1896.

Saif, Liana. "What is Islamic Esotericism?" Correspondences: Journal for the Study of Esotericism vol 7, no. 1 (2019): 1-59.

Saler, Benson. Conceptualizing Religion: Immanent Anthropologists, Transcendent Natives, and Unbounded Categories. Leiden: Brill, 1993.

Teuwsen, Rudolf, Familienähnlichkeit und Analogie: Zur Semantik genereller Termini bei Wittgenstein und Thomas von Aquin. Freiburg i. Br.: Alber, 1988.

Schmidt-Biggemann, Wilhelm. Philosophia perennis: Historische Umrisse abendländischer Spiritualität in Antike, Mittelalter und Früher Neuzeit. Frankfurt am Main: Suhrkamp, 1998.

Schubert, Anselm. Täufertum und Kabbalah: Augustin Bader und die Grenzen der Radikalen Reformation. Gütersloh: Gütersloher Verlagshaus, 2008.

Sedgwick, Mark. "Islamic and Western Esotericism." Correspondences: Journal for the Study of Esotericism 7, no. 1 (2019): 277-299.

Simpson, John Andrew, and Edmund S. C. Weiner, ed. The Oxford English Dictionary. Vol. 7. Oxford: Clarendon Press, 1989.

Sinnett, Alfred Percy. Esoteric Buddhism. London: Trübner, 1883.

Stausberg, Michael. "Religion: Begriff, Definitionen, Theorien." In Religionswissenschaft, edited by Michael Stausberg, 33-47. Berlin/Boston: de Gruyter, 2012.

Steuco, Agostino. De Perenni philosophia libri X. Lyon: Gryphius, 1540.

Strube, Julian. Sozialismus, Katholizismus und Okkultismus im Frankreich des

19. Jahrhunderts: Die Genealogie der Schriften von Eliphas Lévi. Boston: De Gruyter, 2016.

_. "Occultist Identity Formations Between Theosophy and Socialism in fin-de-siècle France." Numen 64,5-6 (2017): 568-595.

—. "Towards the Study of Esotericism Without the 'Western': Esotericism from the Perspective of a Global Religious History." In New Approaches to the Study of Esotericism, edited by Egil Asprem and Julian Strube, forthcoming.

Stuckrad, Kocku von. Was ist Esoterik? Kleine Geschichte des geheimen Wissens. München: C. H. Beck, 2004.

- Locations of Knowledge in Medieval and Early Modern Europe: Esoteric Discourse and Western Identities. Leiden/Boston: Brill, 2010.

Wels, Volkhard. 'Zwischen Spiritualismus, Hermetik und lutherischer 'Orthodoxie': Zu HansGeorg Kempers Vorgeschichte der Naturlyrik.” Zeitsprünge 16, 3/4 (2012): 243-285. 
Yildirim, Cüneyd. "Sufismus als Esoterik." Zeitschrift für junge Religionswissenschaft 13 (2018): Accessed on 31 January 2019. doi: 10.4000/zjr.948.

Zander, Helmut. "Das Konzept der 'Esoterik' im Bermudadreieck von Gegenstandsorientierung, Diskurstheorie und Wissenschaftspolitik: Mit Überlegungen zur konstitutiven Bedeutung des identitätsphilosophischen Denkens." In Aufklärung und Esoterik. Vol. 3, Wege in die Moderne, edited by Monika Neugebauer-Wölk, Renk Geffarth, and Markus Neuman, 113-135. Berlin/Boston: de Gruyter, 2013.

Zarcone, Thierry. "Occultism in an Islamic context: the case of modern Turkey from the nineteenth century to the present time." In Occultism in a Global Perspective, edited by Henrik Bogdan and Gordan Djurdjevic, 151-176. Durham: Acumen, 2013.

Zimmermann, Rolf Christian. Das Weltbild des jungen Goethe: Studien zur hermetischen Tradition des deutschen 18. Jahrhunderts. Vol 1, 2nd enl. and rev. ed. München: Fink, 2002. 